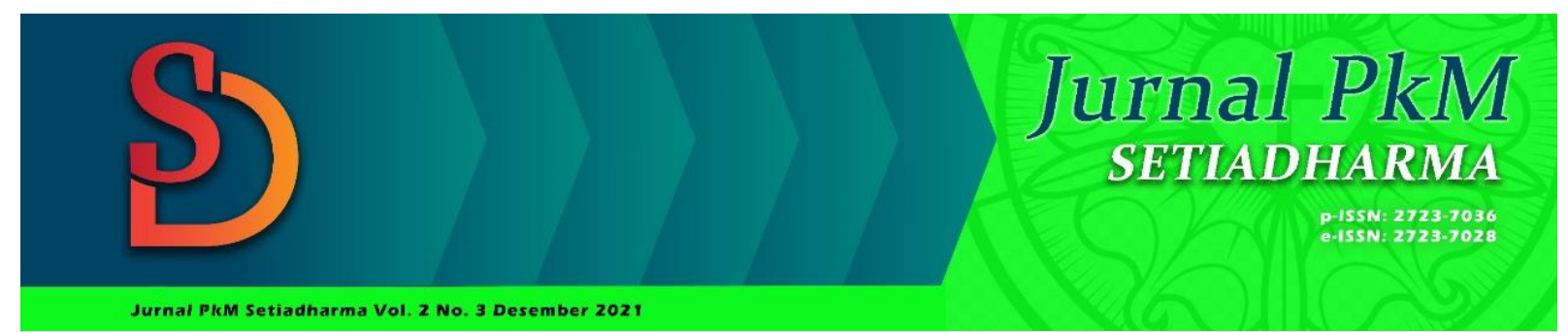

\title{
PERTUMBUHAN IMAN KAUM TUNANETRA KEPADA KRISTUS DI MASA PANDEMI COVID-19 DI JAWA BARAT, JAKARTA DAN MEDAN
}

\author{
Tjutjun Setiawan, Andreas Kurniawan, Ronald Rachmat, Linutama Setiyawan, \\ Sekolah Tinggi Teologi Kharisma Bandung \\ tjutjun.setiawan65@gmail.com, andre.kaizenskinexpert@gmail.com, \\ ronald.rachmat@gmail.com, iwansetiyawan0508@gmail.com,
}

Diterima:
24-07-2021
Direview:
28-07-2021
24-09-2021
Direvisi:
20-08-2021
07-10-2021
Diterbitkan:
31-12-2021
Keywords:
Bible, braille, blind,
devotion, covid-19
Kata Kunci:
Alkitab, braille,
tunanetra,
pengabdian, covid-
19

Diterima:

Direview:

28-07-2021

24-09-2021

Direvisi:

20-08-2021

07-10-2021

Diterbitkan:

31-12-2021

Keywords:

Bible, braille, blind, devotion, covid-19

Kata Kunci: Alkitab, braille, tunanetra, 19

\section{Abstract}

During the Covid-19 pandemic, the church was limited by government regulations not to hold on-site service but was replaced with online service via YouTube, Zoom Meetings or other media. Not everyone can use this technology, especially those who have limitations as experienced by the blind. As believers they still have to grow in faith. The problem in the research is how blind people continue to grow in faith in Christ even during the Covid-19 pandemic? This study uses a qualitative method with a literature study approach together with interviews with blind people about the need for their growth in faith. The growth in faith can be obtained through worship, Bible reading. By stopping the weekly service as usual, it is through reading the Bible that they gain faith growth. But they are constrained by funding problems to have a special Bible for them. The result of this research is that the blind need Braille Bible. The author lists the needs of the Braille Bible and distributes it for free as a form of community service. The author hopes that this research can raise the concern of Christians for the needs of the blind and those who need help.

\section{Abstrak}

Pada masa pandemi Covid-19, gereja dibatasi aturan pemerintah untuk tidak mengadakan ibadah secara onsite tetapi diganti dengan ibadah online melalui YouTube, Zoom Meeting atau media yang lain. Tidak semua orang dapat memanfaatkan teknologi ini terutama mereka yang mempunyai keterbatasan sebagaimana dialami kaum tunanetra. Sebagai orang percaya mereka tetap harus bertumbuh dalam iman. Rumusan masalah dalam penelitian adalah bagaimana kaum tunanetra tetap bertumbuh dalam iman kepada Kristus meskipun di masa pandemi Covid-19? Penelitian ini menggunakan metode kualitatif dengan pendekatan studi kepustakaan dibarengi dengan wawancara terhadap kaum tunanetra tentang kebutuhan akan pertumbuhan iman mereka. Pertumbuhan iman bisa didapat melalui ibadah, pembacaan Alkitab. Dengan dihentikan ibadah minggu seperti biasa maka melalui pembacaan Alkitablah mereka mendapatkan pertumbuhan iman. Tetapi mereka terkendala masalah dana untuk memiliki Alkitab khusus bagi mereka. Hasil dari penelitian ini adalah kaum tunanetra membutuhkan Alkitab Braille. Penulis mendata kebutuhan Alkitab Braille dan membagikannya secara gratis sebagai bentuk pengabdian kepada masyarakat. Penulis berharap penelitian ini dapat membangkitkan kepedulian umat Kristen akan kebutuhan kaum tunanetra maupun mereka yang membutuhkan pertolongan. 


\section{PENDAHULUAN}

Wabah virus corona (Covid-19) yang berkepanjangan telah mengubah tatanan kehidupan masyarakat sehari-hari. Pada bulan Maret tahun 2020. Presiden Joko Widodo mengumumkan bahwa Indonesia sudah mulai dijangkiti oleh virus corona yang dikenal dengan sebutan Covid-19,1 dan pada akhirnya Covid-19 telah dinyatakan sebagai pandemi global dan telah menyebar ke banyak negara di seluruh dunia. Covid-19 menyebar dengan cepat melalui kontak langsung maupun melalui droplet (tetesan pernapasan) dari orang yang telah terpapar atau terinfeksi. ${ }^{2}$

Dari sejak saat itu tatanan kehidupan masyarakat berubah, baik dalam pekerjaan, kehidupan sehari-hari di mana masyarakat sekarang ini harus terbiasa dengan pola hidup bersih, selalu mencuci tangan, selalu memakai masker dan juga dalam pergaulan sosial mengalami perubahan, tidak lagi bisa seperti sebelum pandemi terjadi. Bahkan dalam tatanan kehidupan beribadah juga mengalami perubahan, di mana masyarakat kristiani yang biasa selalu beribadah pada hari Minggu dan bahkan mengadakan acaraacara rohani di gereja dengan datang secara langsung, kini semua itu diatur oleh pemerintah. Jika kasus-kasus baru melandai maka jemaat bisa hadir secara fisik di gereja dengan aturan yang ketat di mana protokol kesehatan dilakukan secara ketat dan juga kehadiran jemaat dibatasi jumlah dalam kehadiran tiap-tiap ibadahnya. Jika keadaan kasus baru yang terjangkit Covid-19 semakin meningkat maka ibadah langsung di gereja ditiadakan dan diganti dengan ibadah secara online.

Pemberlakuan Pembatasan Sosial Berskala Besar (PSBB) adalah suatu kebijakan protokol pencegahan Covid-19 di Indonesia yang diterapkan di beberapa wilayah yang memiliki kasus positif Covid-19 terbanyak. Dengan berlakunya PSBB memiliki dampak kepada seluruh lapisan masyarakat dalam aspek sosial, ekonomi, maupun lingkungan. ${ }^{3}$ Hal ini dikarenakan dibatasinya kegiatan masyarakat di luar rumah dan penutupan fasilitas umum seperti sekolah diliburkan dan tempat kerja, penutupan tempat ibadah dan objek wisata, termasuk pembatasan transportasi umum. ${ }^{4}$ Dampak tersebut pun dirasakan oleh kelompok rentan seperti penyandang disabilitas dengan beragam disabilitasnya yang salah satunya adalah komunitas tunanetra yang banyak dari komunitas ini kehilangan mata pencaharian. ${ }^{5}$

Selain berdampak pada kehidupan ekonomi mereka, tetapi juga berdampak kepada kehidupan rohani mereka, di mana mereka tidak bisa lagi beribadah sebagaimana biasanya. Di masa sebelum pandemi saja tidak mudah bagi mereka untuk beribadah karena keterbatasan gereja menyediakan sarana untuk penyandang disabilitas. ${ }^{6}$ Mereka harus berdiam diri di rumah dan mengikuti secara online yang tentu saja tidak mudah bagi mereka untuk melakukan seperti itu.

Meskipun mereka memiliki keterbatasan tetapi kelompok disabilitas Kristen mempunyai kebutuhan yang sama seperti orang Kristen pada umumnya, mereka membutuhkan eksistensi, relasi dan bertumbuh di dalam Kristus. ${ }^{7}$ Juga mempunyai

\footnotetext{
${ }^{1}$ Desca Lidya Natalia and Hanni Sofia, "Presiden Umumkan Kasus Infeksi Corona Pertama Di Indonesia," Antaranews.Com.

${ }^{2}$ Aldi Ahmad Rifai and Sahadi Humaedi, "INKLUSI PENYANDANG DISABILITAS DALAM SITUASI PANDEMI COVID-19 DALAM PERSPEKTIF SUSTAINABLE DEVELOPMENT GOALS (SDGs)," Prosiding Penelitian dan Pengabdian kepada Masyarakat (2020).

${ }^{3}$ Ibid.

${ }^{4}$ Ibid

${ }^{5}$ Dani Prabowo, “Ada Yang Lebih Susah Dari Kita, Yaitu Penyandang Disabilitas,” Kompas.Com.

${ }^{6}$ Arie Nugraha, "Rumah Ibadah Di Bandung Belum Ramah Bagi Disabilitas," Liputan6.Com.

${ }^{7}$ Sigit Triyono, "Alkitab Dan Disabilitas - Lembaga Alkitab Indonesia," Https://Indonesia.Bible.
} 
PERTUMBUHAN IMAN KAUM TUNANETRA ... (Tjutjun Setiawan, Andreas Kurniawan, Ronald Rachmat, Linutama Setiyawan, Ferry Simanjuntak)

kebutuhan untuk dapat mengakses dan membaca Alkitab, sehingga mereka dapat bertumbuh dalam iman.

Dari paparan di atas didapat rumusan masalah yang akan diteliti yaitu bagaimana kaum tunanetra tetap bertumbuh dalam iman kepada Kristus meskipun di masa pandemi Covid-19? apa yang menjadi kebutuhan kaum tunanetra supaya iman mereka dapat tetap bertumbuh meskipun di tengah pandemi Covid-19? dan bagaimana membantu mereka dalam hal pertumbuhan iman tersebut?

Adapun tujuan dari penelitian ini adalah supaya kaum tunanetra yang sangat rentan terdampak dalam pandemi yang terjadi di Indonesia ini tetap dapat bertumbuh dalam iman dan pengharapan dalam Kristus. Penulis juga berharap dengan penelitian ini dapat menggerakkan dan membangkitkan kepedulian dari setiap orang Kristen yang mempunyai berkat lebih terhadap kaum penyandang disabilitas pada umumnya dan tunanetra pada khususnya.

\section{METODE PELAKSANAAN}

Metode yang digunakan dalam penelitian ini adalah kualitatif dengan pendekatan studi kepustakaan (library research). ${ }^{8}$ Penulis mengumpulkan data dari informasi internet, buku-buku, jurnal, dan juga Alkitab, yang berkaitan dengan masalah yang diteliti, ${ }^{9}$ menggali dan mendalami apa yang menjadi kebutuhan kelompok tunanetra di Jawa Barat, Jakarta dan Medan supaya iman mereka tetap bertumbuh di tengah keterbatasan mereka dan di masa pandemi Covid-19 ini di mana ada pembatasan dalam beribadah secara langsung. Penulis juga melakukan wawancara dengan kaum tunanetra ini, ${ }^{10}$ sehingga dengan demikian dapat dihasilkan suatu pembahasan yang objektif dan menyeluruh, dapat dipertanggungjawabkan, yang pada akhirnya didapat suatu kesimpulan yang menjawab rumusan masalah dalam penelitian ini dan dapat membantu kaum tunanetra akan pertumbuhan imannya. Pengabdian kepada masyarakat ini persiapannya dimulai pada bulan Desember 2020.

\section{HASIL DAN PEMBAHASAN}

\section{Definisi Tunanetra}

Kata Tuna mengandung beberapa arti harfiah: luka; rusak; kurang; tidak memiliki. ${ }^{11}$ Berasal dari Bahasa Jawa kuno yang berarti rusak atau rugi, tetapi kata ini tidak biasa digunakan untuk mengacu kepada barang yang rusak, seperti halnya kata cacat. Pada awalnya istilah tuna ini digunakan untuk memperhalus kata cacat sebagai bentuk tetap menghormati penyandangnya. ${ }^{12}$ Dapat dihubungkan dengan kekurangan fungsi tubuh dalam diri seseorang seperti tunadaksa (cacat tubuh); tunagrahita (cacat pikiran, keterbelakangan mental; tunanetra (tidak dapat melihat, buta). ${ }^{13}$

\footnotetext{
${ }^{8}$ Sugiyono, Metode Penelitian Kuantitatif Kualitatif Dan R\&D (Bandung: Alfabeta, 2011).

${ }^{9}$ Ferry Simanjuntak, Metode Penelitian (Bandung: Sekolah Tinggi Teologi Kharisma, 2016).

${ }^{10}$ Samuel Santoso, "Wawancara" (Solo, 2020).

${ }^{11}$ Dini Widinarsih, "Penyandang Disabilitas Di Indonesia: Perkembangan Istilah Dan Definisi," Jurnal Ilmu Kesejahteraan Sosial (2019).

12 Ibid.

13 Ibid.
} 
Tunanetra menurut Kamus Besar Bahasa Indonesia adalah tidak dapat melihat; buta. ${ }^{14}$ Tunanetra termasuk ke dalam kelompok difabel atau penyandang cacat, yang memiliki hambatan dalam penglihatan. Tunanetra dapat diklasifikasikan kedalam dua golongan yaitu: buta total (blind) dan low vision. Definisi tunanetra menurut Kaufman \& Hallahan adalah individu yang memiliki lemah penglihatan atau akurasi penglihatan kurang dari 6/60 setelah dikoreksi atau tidak lagi memiliki penglihatan. ${ }^{15}$ Karena tunanetra memiliki keterbatasan dalam indera penglihatan maka proses pembelajaran menekankan pada alat indera yang lain yaitu indera peraba dan indera pendengaran. Tunanetra adalah mereka yang tidak memiliki penglihatan sama sekali (buta total) hingga mereka yang masih memiliki sisa penglihatan tetapi tidak mampu menggunakan penglihatannya.

Menurut Undang-Undang Nomor 8 Tahun 2016 tentang Penyandang Disabilitas, setiap orang yang mengalami keterbatasan fisik, intelektual, mental dan/atau sensorik dalam jangka waktu lama yang dalam berinteraksi dengan lingkungan dapat mengalami hambatan dan kesulitan untuk berpartisipasi secara penuh dan efektif dengan warga negara lainnya berdasarkan kesamaan hak. ${ }^{16}$ Lebih lanjut dinyatakan bahwa jenis disabilitas dikaregorikan menjadi empat yaitu disabilitas fisik, intelektual, mental, dan/atau sensorik. ${ }^{17}$ Tunanetra termasuk ke dalam kategori disabilitas sensorik yaitu penyandang disabilitas yang fungsi panca indera yaitu penglihatan terganggu. ${ }^{18}$

\section{Klasifikasi Tunanetra}

Sebagai organisasi Kesehatan dunia, World Health Organization (WHO) berdasarkan International Statistical Classification of Diaseases and Related Health Problems, 10th revision (ICD-10) telah memberikan definisi tentang kebutaan sebagai tajam penglihatan kurang dari 3/60 atau lapang pandang kurang dari 10 derajat pada mata terbaik dengan koreksi refraksi yang tersedia. Adapun gangguan penglihatan sedang dikategorikan jika seseorang memiliki tajam penglihatan diatas 6/60 namun kurang dari 6/18. Sedangkan gangguan penglihatan berat dikategorikan jika seseorang memiliki tajam penglihatan di bawah 6/60 namun lebih dari 3/60. Kategori 1 dan 2 disebut dengan low vision dan kategori 3 - 5 disebut dengan kebutaan. ${ }^{19}$

Tunanetra ringan (defective vision/low vision) adalah seseorang yang memiliki gangguan dalam penglihatan namun mereka masih bisa mengikuti kegiatan pendidikan atau proses pembelajaran dan mampu melakukan pekerjaan yang menggunakan fungsi penglihatan. Adapun tunanetra dengan gangguan sedang (partially sighted) adalah seseorang yang kehilangan sebagian daya penglihatan, hanya dengan menggunakan kaca pembesar mampu mengikuti pendidikan biasa dan atau mampu membaca tulisan berhuruf tebal. Tunanetra dengan gangguan berat (totally blind) yakni mereka yang sama sekali tidak dapat melihat, dan mengalami kebutaan total. ${ }^{20}$

Tunanetra dapat dikelompokkan sebagai berikut: tunanetra sejak lahir terdiri dari orang yang mengalami kebutaan pada saat dalam kandungan; tunanetra setelah lahir atau pada usia kecil; tunanetra yang mengalami pada usia sekolah anak atau

\footnotetext{
14 “Arti Kata Tunanetra - Kamus Besar Bahasa Indonesia (KBBI) Online” (KBBI Online, 2021).

${ }^{15}$ Halahan D.P and Kauffman J.M, Exceptional Learners: Introduction to Special Education, 10th ed. (USA: Pearson, 2006).

${ }^{16}$ Vanaja Syifa Radissa et al., "PEMENUHAN KEBUTUHAN DASAR PENYANDANG DISABILITAS PADA MASA PANDEMI COVID-19," Focus : Jurnal Pekerjaan Sosial (2020).

17 Ibid.

18 Ibid.

${ }^{19}$ Nadia Khairina Budiman, Penyebab Dan Pencegahan Kebutaan (Bandung, 2019).

${ }^{20}$ Kirk. A Samuel, Klasifikasi Kebutaan (USA, 1991).
} 
PERTUMBUHAN IMAN KAUM TUNANETRA ... (Tjutjun Setiawan, Andreas Kurniawan, Ronald Rachmat, Linutama Setiyawan, Ferry Simanjuntak)

remaja; tunanetra dewasa adalah orang dewasa yang mengalami kebutaan pada usia dewasa; dan tunanetra yang mengalami kebutaan pada usia lanjut. ${ }^{21}$

Faktor yang menyebabkan gangguan pada penglihatan terbanyak di seluruh dunia adalah gangguan refraksi yang tidak terkoreksi $(48,99 \%)$, katarak $(25,81 \%)$ dan Age related Macular Degeneration (AMD, 4,1\%). Sedangkan faktor terbanyak yang menyebabkan kebutaan adalah katarak $(34,47 \%)$, lalu gangguan refraksi yang tidak terkoreksi (20,26\%), dan glukoma (8,30\%). Lebih dari 75\% gangguan penglihatan adalah gangguan penglihatan yang dapat dicegah. Katarak atau kekeruhan lensa mata adalah penyebab utama kebutaan di Indonesia, 77,7\% kebutaan dikarenakan katarak. Sedangkan prevalensi kebutaan akibat katarak pada penduduk umur 50 tahun ke atas di Indonesia sebesar 1,9\%. Katarak adalah merupakan proses degeneratif yang sangat dipengaruhi umur. Dengan meningkatnya umur harapan hidup maka proporsi penduduk umur $\geq 50$ tahun akan meningkat sehingga jumlah penderita katarak juga akan makin meningkat. ${ }^{22}$

\section{Huruf Braille}

Braille adalah suatu sistem membaca dan menulis yang digunakan oleh tunanetra sehingga ia mendapatkan informasi pengetahuan. Menguasai Kode braille membawa penglihatan bagi orang-orang tunanetra dan memainkan peran penting dalam kehidupan mereka. Di era digital seperti sekarang ini, individu tunanetra memiliki banyak pilihan yang sangat efektif untuk komunikasi. Terbaru teknologi telah memungkinkan mereka untuk menjadi bagian dari masyarakat berpengetahuan dengan memungkinkan mereka untuk memahami isi situs web atau buku apa pun. ${ }^{23}$

Hambatan di dalam penglihatan mengakibatkan kaum tunanetra mengalami kesulitan dalam menerima informasi dalam bentuk visual, juga termasuk dalam bentuk tulisan. Dalam keterbatasannya mereka lebih mengoptimalkan kepekaan indera lain seperti indera pendengaran, indera penciuman, dan indera raba. Karena itu, bagi mereka, informasi yang sebelumnya dalam bentuk visual harus diubah menjadi bentuk lain seperti bunyi suara, bau-bauan, atau sentuhan untuk memudahkan penyandang tunanetra menerima informasi. 24

Huruf braille adalah huruf dengan sistem tulisan sentuh yang digunakan oleh penyandang disabilitas tunanetra untuk membaca dan menulis. Sistem ini pertama kali digunakan di L'Institution Nationale des Jeunes Aveugles, Paris, dalam rangka mengajar siswa-siswa tunanetra. Dengan ditemukannya sistem ini membawa harapan bagi kaum tunanetra untuk mengakses dan mendapatkan informasi dalam bentuk tulisan sekaligus memudahkan dalam proses pendidikan. Penemu dari sistem sentuh huruf braille ini diciptakan oleh seorang tunanetra asal Perancis, yang bernama Louis Braille, itulah mengapa huruf tersebut disebut huruf Braille mengacu kepada nama penemunya. ${ }^{25}$

\footnotetext{
${ }^{21}$ Ade Nasihudin Al Ansori, “4 Klasifikasi Tunanetra Berdasarkan Jenis Kelainan Hingga Waktu Terjadinya," Http://Liputan6.Com.

${ }^{22}$ Fetty Ismandari, Situasi Gangguan Penglihatan, Infodatin Kemenkes RI (Jakarta, 2018).

${ }^{23}$ Zaid Haron Musa Jawasreh, Noraidah Sahari Ashaari, and Dahlila Putri Dahnil, "The Acceptance of Braille Self-Learning Device," International Journal on Advanced Science, Engineering and Information Technology (2020).

${ }^{24}$ Farid Afandi, Mari Mengenal Huruf Braille (Sidoarjo, 2017).

25 Ibid.
} 


\section{Bertumbuh dalam Iman}

Dalam Roma 10:17, “Jadi, iman timbul dari pendengaran, dan pendengaran oleh firman Kristus." Seseorang yang ingin bertumbuh imannya tidak bisa dilepaskan dari firman Yesus Kristus, dan itu hanya akan bisa didapat dengan membaca Alkitab dan mendengarkan Alkitab yang adalah firman Tuhan.

Rasul Paulus menasihati Timotius untuk selalu mengingat dan memberi perhatian pada Alkitab, yang pada zaman itu hanya ada perjanjian Lama, "Ingatlah juga bahwa dari kecil engkau sudah mengenal Kitab Suci yang dapat memberi hikmat kepadamu dan menuntun engkau kepada keselamatan oleh iman kepada Kristus Yesus." (2Tim. 3:15). ${ }^{26}$ Bahkan dituliskan lebih lanjut mengenai manfaat yang bisa diperoleh dengan mendalami Alkitab sebagaimana tertulis dalam 2 Timotius 3:16, "Segala tulisan yang diilhamkan Allah memang bermanfaat untuk mengajar, untuk menyatakan kesalahan, untuk memperbaiki kelakuan dan untuk mendidik orang dalam kebenaran." Jadi di dalam Alkitab ada banyak pengajaran-pengajaran, bermanfaat untuk menyatakan kesalahan, dan untuk memperbaiki kelakuan dan juga membawa orang ke dalam kebenaran yang berpusat pada Kristus. Dengan bertekun dalam firman Tuhan akan terjadi pertumbuhan baik pribadi maupun dalam jemaat sebagaimana jemaat mulamula bertekun dalam pengajaran rasul-rasul dan mengalami pertumbuhan (Kis. 2:42). ${ }^{27}$

\section{Alkitab Standar dan Alkitab Braille}

Kata Alkitab berasal dari kata dalam bahasa Yunani yaitu biblion atau biblos yang artinya adalah gulungan atau buku. ${ }^{28}$ Alkitab seringkali disebut Kitab Suci yang dalam bahasa Inggris disebut Scripture yang dapat diatikan firman, dan dalam bahasa Latin, Alkitab disebut Scriptura atau dalam bahasa Yunani dengan sebutan Graphe. ${ }^{29}$ Alkitab adalah firman Allah, kebenaran dari Allah, ${ }^{30}$ firman yang tertulis, wahyu yang sempurna yang diadakan Allah melalui proses yang panjang. ${ }^{31}$ Dalam menyatakan diri-Nya kepada manusia, Allah menggunakan berbagai sarana dan Alkitab adalah salah satunya, sebuah sarana yang istimewa sebab Alkitab adalah firman Allah. ${ }^{32}$

Alkitab terdiri dari dua kumpulan tulisan kudus yang disebut Perjanjian Lama yang berisi 39 kitab dan Perjanjian Baru yang berisi 27 kitab sehingga dengan demikian jumlahnya adalah 66 kitab. ${ }^{33}$ Kitab-kitab itu memuat tentang sejarah, hukum, nubuat, hikmat, puisi, surat-surat, dan apokaliptis. ${ }^{34}$ Dan inti dari keseluruhan kitab adalah berbicara tentang Yesus yang dinubuatkan dalam Perjanjian Lama, tentang Yesus yang datang sebagai penggenapan Mesias yang dijanjikan itu dan Yesus yang akan datang kembali untuk menjemput umat-Nya.

Kaum tunanetra mempunyai kebutuhan untuk dapat mengakses dan membaca Alkitab, sehingga mereka dapat bertumbuh dalam iman. ${ }^{35}$ Kaum disabilitas fisik terutama para tunanetra, tunarungu, dan tunawicara pastilah memiliki keterbatasan

${ }^{26}$ Suhento Liauw, Doktrin Alkitab Alkitabiah (Jakarta: Gereja Baptis Independen Alkitabiah GRAPHE, 2001).

${ }^{27}$ Budisatyo Taniharjo, Integritas Seorang Pemimpin Rohani, ke 5. (Yogyakarta, 2019).

28 Jonar T.H Situmorang, Bibliologi, Ke 5. (Yogyakarta: Penerbit Andi, 2017).

${ }^{29}$ Ibid.

${ }^{30}$ French L Arrington, Doktrin Kristen Perspektif Pentakosta, Ke 6. (Yogyakarta: Penerbit Andi, 2020).

${ }^{31}$ Liauw, Doktrin Alkitab Alkitabiah.

${ }^{32}$ Arrington, Doktrin Kristen Perspektif Pentakosta.

${ }^{33}$ Ibid.

${ }^{34}$ Ibid.

35 Triyono, “Alkitab Dan Disabilitas - Lembaga Alkitab Indonesia.” 
PERTUMBUHAN IMAN KAUM TUNANETRA ... (Tjutjun Setiawan, Andreas Kurniawan, Ronald Rachmat, Linutama Setiyawan, Ferry Simanjuntak)

berinteraksi dengan Alkitab bila menggunakan Alkitab cetak yang standar. Perlu ada Alkitab khusus yang memudahkan mereka berinteraksi dengan Alkitab. ${ }^{36}$

Kesaksian suami isteri Brikjon Purba, bersama istrinya, Laoli, berdomisili di kota Siantar, mereka sama - sama tunanetra, mengungkapkan kegembiraannya dapat membaca Alkitab Braille yang mereka pinjam dari Rumah Baca Mutiara Bangsa. ${ }^{37}$ Mereka sudah lama memiliki kerinduan untuk membaca Alkitab dengan huruf Braille karena dengan keterbatasan mereka tentunya mereka tidak bisa membaca Alkitab cetak standar. Mereka pernah memesan Alkitab Braille tersebut dari rekan-rekan yang lain dan ternyata harganya cukup mahal dan barangnya-pun sulit ditemukan. ${ }^{38}$

Alkitab Braille memang berbeda dengan Alkitab cetak yang standar yang hanya satu buku tebal saja. Sedangkan satu Alkitab Braille Perjanjian Lama dan Perjanjian baru berjumlah 39 buku atau jilid yang jika ditumpukkan menjadi satu maka 1 Alkitab Braille tumpukannya cukup tinggi dengan bobot lebih dari 20 kilogram, adapun rinciannya adalah sebagai berikut:

\begin{tabular}{|l|l|l|}
\hline 1. Kejadian jilid 1 & 14. Mazmur jilid 1 & 27. Matius Jilid 2 \\
2. Kejadian jilid 2 & 15. Mazmur jilid 2 & 28. Markus \\
3. Keluaran jilid 1 & 16. Yesaya jilid 1 & 29. Lukas jilid 1 \\
4. Keluaran jilid 2 & 17. Yesaya jilid 2 & 30. Lukas jilid 2 \\
5. Imamat-Bilangan & 18. Yeremia & 31. Yohanes \\
6. Bilangan-Ulangan & 19. Yehezkiel & 32. Kisah pararasul jilid1 \\
7. Yosua - Hakim2 & 20. Daniel-Hosea & 33. Kisah pararasul jilid2 \\
8. Rut-1 Samuel & 21. Yoel-Mikha & 34. Roma \\
9. Samuel & 22. Habakuk-Maleakhi & 35. \&2 Korintus \\
10. Raja-raja & 23. Tawarikh & 36. Galatia-Kolose \\
11. Raja-raja & 24. Ester & 37. Tesalonika-Filemon \\
12. Ezra-Nehemia & 25. Kidung Agung & 38. Ibrani - 2 Petrus \\
13. Ayub-Pengkotbah & 26. Matius Jilid 1 & 39. Yohanes-Wahyu \\
& & \\
\hline
\end{tabular}

Dengan terbagi menjadi 39 jilid maka meskipun sebuah Yayasan tunanetra tidak memiliki Alkitab dalam jumlah yang banyak tetapi bagian-bagian Alkitab itu bisa dibaca oleh banyak orang secara bergantian dan saling tukar menukar.

\section{Kehidupan yang Berdampak}

Alkitab mengajarkan kepada setiap orang percaya untuk membantu yang lemah sebagaimana tertulis dalam Roma 15:1, "Kita, yang kuat, wajib menanggung kelemahan orang yang tidak kuat dan jangan kita mencari kesenangan kita sendiri." Tuhan Yesus sendiri mengatakan bahwa hendaknya semua orang percaya menjadi garam dan terang dunia sehingga orang-orang melihat perbuatan baik dari setiap orang percaya dan memuliakan Bapa di sorga (Mat. 5:13-16), karena hanya manusia saja yang bisa memuliakan Allah, sedangkan ciptaan yang lain hanya bisa memancarkan kemuliaan

\footnotetext{
${ }^{36}$ Ibid.

${ }^{37}$ Tim, "Bisa Baca Buku Gratis Dan Alkitab Tulisan Braille, Pasangan Suami Istri Tunanetra Apresiasi Rumah Baca Mutiara Bangsa," Https://Hetanews.Com.

${ }^{38}$ Ibid.
} 
Allah. ${ }^{39}$ Ada dampak yang baik dan positif yang diberikan oleh orang percaya pada kehidupan orang lain. ${ }^{40}$ Hendaklah kamu murah hati sama seperti Bapamu adalah murah hati (Luk. 6:36), firman Tuhan yang mengingatkan setiap orang percaya untuk bermurah hati kepada sesama, menolong yang lemah dan berkurangan sebagai wujud ucapan syukur kepada Tuhan sebab Ia sudah menebus dan menyelamatkan setiap orang yang percaya dari dosa. Siapa menaruh belas kasihan kepada orang yang lemah, memiutangi Tuhan, yang akan membalas perbuatannya itu (Ams. 19:17)

\section{Perencanaan}

Berawal dari adanya permintaan Alkitab Braille dari seorang yang bernama Andreas, pendeta GPdI Margatiga, Kabupaten Lampung Timur, yang bersangkutan sebenarnya sudah mempunyai Alkitab Braille tetapi karena sering dipergunakan maka titik timbul dari huruf braille tersebut sudah mulai menipis sehingga menimbulkan kesulitan dalam membacanya. Meskipun sekarang sudah ada Alkitab dalam bentuk audio, tetapi pendeta ini tetap lebih menyukai membaca Alkitab Braille dan untuk itulah ia menyampaikan permintaan kepada penulis.

Penulis mengadakan komunikasi satu dan lainnya melalui media WhatsApp untuk membahas ini, mencari informasi kemana harus mencari Alkitab Braille. Pada akhirnya penulis berkordinasi dengan Lembaga Alkitab Indonesia (LAI), dan setelah melalui proses administrasi, LAI mendukung dan memberikan 1 set Alkitab Braille seperti yang diminta secara gratis dan penulis hanya membayar ongkos kirim saja ke Bandung di mana penulis berdomisili.

Setelah Alkitab Braille tersebut sudah diterima dari LAI Jakarta dan penulis menghubungi pendeta yang mengajukan permintaan itu, ternyata ia sudah mendapatkan kiriman dari temannya yang lain. Dengan adanya kejadian seperti ini lalu penulis kembali berkomunikasi membahas masalah ini. Lalu diputuskan untuk mengadakan aksi pembagian Alkitab yang lebih banyak lagi dengan mendata siapa saja dari kaum tunanetra Kristen yang membutuhkan Alkitab Braille tetapi terkendala dengan dana, baik perorangan maupun yayasan yang menaungi para tunanetra akan penulis bagikan secara gratis tanpa dipungut biaya sedikitpun. Ini dilakukan sebagai bentuk pengabdian kepada masyarakat, menjadi berkat bagi sesama yang membutuhkan. Dan setelah melakukan pendataan penulis berkordinasi kembali dengan LAI untuk meminta Alkitab Braille lebih banyak lagi sebagai tambahan.

\section{Pelaksanaan}

Dari pendataan yang dilakukan, diperoleh data pribadi, Yayasan yang menaungi para tunanetra dan gereja di mana ada anggota jemaatnya yang masuk dalam kelompok tunanetra yang membutuhkan Alkitab Braille, yaitu sebagai berikut:

- Yayasan Elsafan, Jl. Belitung Raya no. 49 RT/RW 5, Pondok Bambu, Duret Sawit, Jakarta Timur, Daerah khusus Ibu Kota Jakarta -13430. Pelaksanaan: dikirim melalui kurir ekspedisi sebanyak 3 set Alkitab.

- Yayasan Pendidikan Tunanetra, Sumatera, KM 21.5 Dusun III. Desa Tanjung Baru, Kecamatan Tanjung Morawa 20362. Kab Deli Serdang, Sumatera Utara. Attn: Bapak Yabes Silaban. Pelaksanaan: dikirim melalui kurir ekspedisi sebanyak 5 set Alkitab.

\footnotetext{
${ }^{39}$ Tony Salurante, Aprianus Moimau, and Filmon Berek, "Tujuan Penciptaan Sebagai Cara Memahami Keberagaman Etika Dalam Kekristenan," Jurnal Teologi Berita Hidup (2021).

${ }^{40}$ Rubin Adi Abraham, Menjadi Berkat Berbuah Lebat, ke 5. (Yogyakarta: Penerbit Andi, 2015).
} 
PERTUMBUHAN IMAN KAUM TUNANETRA ... (Tjutjun Setiawan, Andreas Kurniawan, Ronald Rachmat, Linutama Setiyawan, Ferry Simanjuntak)

- GBI Lippo Cikarang, Perumahan Puri Cijambe blok C12 no, 2e, Sukadami Cikarang Selatan, Kab Bekasi, Attn: Deddy Silalahi. Pelaksanaan: dikirim melalui kurir ekspedisi sebanyak 3 set Alkitab.

- Pdt. Simon. Toko Fatigon. Jl. Mandalagiri 17, Garut. Pelaksanaan: dikirim melalui kurir ekspedisi sebanyak 1 set Alkitab.

- Yayasan Rumah Orang Tua Tunanetra Eben Haizer, Jl. Maribaya no. 24, Lembang, Kab Bandung Barat. Jawa Barat-40391, Attn: Bapak Sitompul. Pelaksanaan: Diberikan langsung kepada pengurus Yayasan sebanyak 4 set.

- Pdt. Dicky Dauhan, Cimahi. Pelaksanaan: Dikirim melalui kurir ekspedisi sebanyak 1 set Alkitab.

- Solo Disability Ministry, Jl. Embarkasi H. Banaran, Gagaksipat, Kec. Ngemplak, Kab Boyolali, Jawa Tengah - 57375. Attn: Samuel Santoso

Telepon: +628122311381, +628586134355, Pelaksanaan: Diserahkan langsung kepada yang bersangkutan sebanyak 1 Set Alkitab.

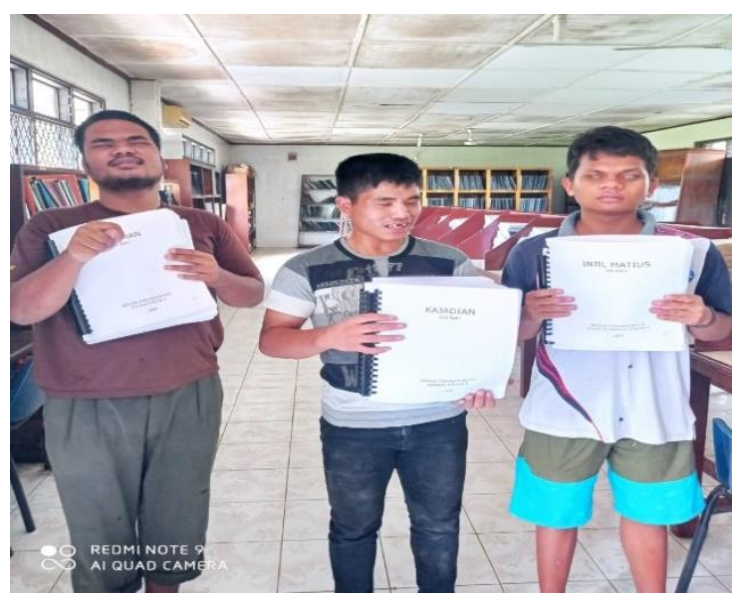

Pelaksanaan penyerahan Alkitab Braille dilakukan dengan 2 metode yaitu metode pengiriman melalui kurir/ekspedisi dan penyerahan langsung di mana Akitab tersebut diserahkan langsung oleh para penulis kepada yang membutuhkan dengan menggunakan protokol kesehatan yang ketat karena masih berada dalam pandemi Covid-19.

Sehubungan dengan pandemi covid-19 ini di mana ada pembatasan ruang gerak sebagaimana di atur oleh keputusan pemerintah, maka tidak semua Yayasan atau penerima dari pembagian Alkitab Braille ini dikunjungi oleh penulis, hanya beberapa saja yang dapat dikunjungi dan itupun dengan protokol kesehatan yang ketat.

Pembagian Alkitab Braille ini merupakan kegiatan tanpa dipungut biaya sedikitpun, penulis memberikan kepada para penerima sebagaimana dituliskan di atas secara gratis. Biaya pengiriman Alkitab tersebut baik dari LAI ke Bandung ke tempat di mana penulis berdomisili maupun biaya pengiriman ke masing-masing penerima Alkitab tersebut, semua biaya menjadi tanggung jawab dari para penulis secara kolektif sebagai bentuk berbagi kasih dan bentuk kepedulian kepada sesama anak Tuhan yang membutuhkan.

Mengingat bahwa kaum tunanetra ini adalah kelompok yang sudah dapat membaca huruf braille, maka penulis tidak melakukan kegiatan mengajar huruf tetapi penulis memberikan motivasi dan mendorong penerima baik yang dikunjungi langsung maupun yang dikunjungi melalui sarana komunikasi yang tersedia untuk memanfaatkan Alkitab Braille tersebut dengan membaca serta merenungkannya karena itu akan 
berdampak bagi pertumbuhan iman mereka sebagaimana tertulis dalam Roma 10:17, "Jadi iman timbul dari pendengaran, dan pendengaran oleh firman Kristus."

\section{Pengawasan}

Terhadap Alkitab yang diserahkan langsung tentunya tidak dibutuhkan pengawasan karena Alkitab-Alkitab tersebut diserahkan dan diterima secara langsung baik yang mengatasnamakan pribadi maupun Yayasan dan serah terimanya didokumentasikan. Tetapi untuk Alkitab-Alkitab yang pengirimannya dilakukan melalui jasa kurir/ekspedisi, penulis melakukan pemantauan atau pengawasan sampai kiriman tersebut diterima oleh pribadi maupun Yayasan yang membutuhkan, dan penulis melakukan komunikasi dengan pihak penerima dalam hal ini dan juga penulis meminta kepada mereka untuk dibuatkan photo penerimaan jika sudah diterima sehingga terdokumentasi dengan baik dan lebih daripada itu apa yang mereka butuhkan yaitu Alkitab Braille di mana mereka dapat membacanya, merenungkan firman Tuhan sehingga iman mereka bertumbuh dapat terpenuhi dengan baik.

\section{Evaluasi dan Tindak Lanjut}

Dari 39 jilid yang seharusnya ada dalam 1 set Alkitab tersebut, yang penulis kirim baru 29 jilid saja dikarenakan 10 jilid yang lain stoknya sedang kosong di LAI. Jika yang 10 jilid itu sudah tersedia, maka penulis merencanakan akan melakukan pengiriman kembali untuk kekurangan tersebut. Tidak tertutup kemungkinan jika di kemudian hari ada permintaan yang baru dari kaum tunanetra yang lain, sebagai bentuk pelayanan dan pengabdian kepada masyarakat maka penulis akan memproses permintaan itu sebagaimana yang telah dilakukan sebelumnya.

Respons dari mereka yang menerima Alkitab Braille tersebut sungguh baik dan mereka sungguh bersukacita menerimanya sebab sudah lama mereka mendambakan memiliki Alkitab Braille untuk memenuhi kerinduan mereka akan pembacaan firman Tuhan.

Penulis menghubungi yayasan yang menjadi penerima seperti Yayasan Pendidikan Tunanetra Medan untuk memantau sejauh mana manfaat dari pengabdian yang penulis lakukan. Di yayasan tersebut ada 64 orang tunanetra dari berbagai kelompok usia dan setiap hari dari senin sampai saptu diadakan ibadah sebanyak dua kali, yaitu pagi dan sore, di mana peserta ibadah secara bergantian membaca Alkitab Braille tersebut dan merenungkannya.

\section{UCAPAN TERIMA KASIH}

Pengabdian kepada masyarakat dalam hal membagikan Alkitab Braille kepada kaum tunanetra sehingga mereka dapat membaca Alkitab yang adalah firman Tuhan dengan tulisan yang dapat mereka pahami sehubungan dengan adanya hambatan yang mereka miliki dalam hal melihat, sehingga dengan demikian mereka dapat bertumbuh dalam iman kepada Kristus.

Penulis mengucap syukur kepada Tuhan atas pelaksanaan ini dan juga penulis berterimakasih kepada Lembaga Alkitab Indonesia (LAI) yang telah menjalin kerjasama dengan penulis sehingga pengabdian kepada masyarakat ini dapat terlaksana. 

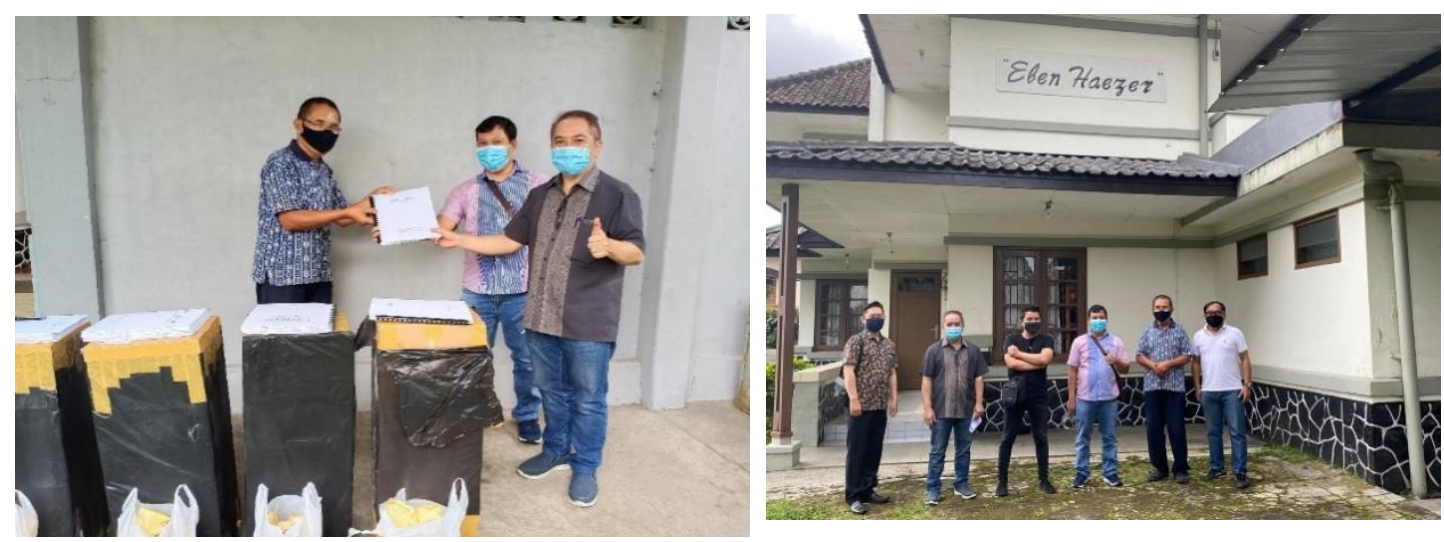

\section{KESIMPULAN}

Alkitab adalah firman Allah. Di mana di dalamnya nyata kebenaran Allah, bermanfaat bagi setiap orang, ada banyak pengajaran-pengajaran, untuk menyatakan kesalahan, untuk memperbaiki kesalahan dan pada akhirnya membawa orang pada kebenaran, mendidik orang pada kebenaran. Bagi orang yang tidak termasuk kategori penyandang disabilitas fisik seperti tunanetra tentu saja tidak mempunyai hambatan dalam membaca Alkitab cetak standar, tetapi bagi kaum tunanetra ini menjadi masalah. Mereka membutuhkan Alkitab khusus yang ditulis dalam huruf Braille di mana mereka membacanya dengan memakai indera peraba. Faktor kesulitan untuk mendapatkan Alkitab berhuruf Braille dan juga ketiadaan dana yang menyebabkan tidak semua tunanetra memiliki Alkitab Braille ini. Dengan melakukan kegiatan pengabdian kepada masyarakat yang penulis lakukan untuk memenuhi kebutuhan kaum tunanetra untuk tetap bertumbuh dalam iman apalagi dalam masa pandemi Covid-19 ini di mana gereja di dalam melakukan ibadahnya berganti dengan cara online melalui media YouTube, Zoom Meeting atau aplikasi yang lain yang tentu saja tidak mudah juga bagi kaum tunanetra ini untuk mengaksesnya, beribadah dan bertumbuh dalam iman. Adapun kegiatan yang dilakukan adalah dengan membagikan Alkitab Braille itu kepada mereka yang sebelumnya sudah penulis data baik itu perorangan maupun Yayasan yang menaungi beberapa tunanetra dan juga gereja yang memiliki anggota jemaat yang mengalami keterbatasan dalam melihat. Semua diberikan secara gratis dan tidak dipungut biaya sedikitpun.

Melalui kegiatan pengabdian masyarakat ini penulis menggugah setiap orang Kristen yang mempunyai kemampuan keuangan atau berkat yang lebih untuk tergerak, bangkit, dan mulai peduli akan kebutuhan kaum tunanetra ini maupun juga kepada mereka yang membutuhkan pertolongan. 


\section{DAFTAR PUSTAKA}

Abraham, Rubin Adi. Menjadi Berkat Berbuah Lebat. Ke 5. Yogyakarta: Penerbit Andi, 2015.

Afandi, Farid. Mari Mengenal Huruf Braille. Sidoarjo, 2017.

Al Ansori, Ade Nasihudin. "4 Klasifikasi Tunanetra Berdasarkan Jenis Kelainan Hingga Waktu Terjadinya." Http://Liputan6.Com.

Arrington, French L. Doktrin Kristen Perspektif Pentakosta. Ke 6. Yogyakarta: Penerbit Andi, 2020.

Bebeng, Agus. "Sejarah Hari Braille Sedunia Di Tengah Ancaman Teknologi." Http://Www.Kumparan.Com.

Budiman, Nadia Khairina. Penyebab Dan Pencegahan Kebutaan. Bandung, 2019.

D.P, Halahan, and Kauffman J.M. Exceptional Learners: Introduction to Special Education. 10th ed. USA: Pearson, 2006.

Hsu, Bi Min. "Braille Recognition for Reducing Asymmetric Communication between the Blind and Non-Blind." Symmetry (2020).

Ismandari, Fetty. Situasi Gangguan Penglihatan. Infodatin Kemenkes RI. Jakarta, 2018.

Jawasreh, Zaid Haron Musa, Noraidah Sahari Ashaari, and Dahlila Putri Dahnil. "The Acceptance of Braille Self-Learning Device." International Journal on Advanced Science, Engineering and Information Technology (2020).

Liauw, Suhento. Doktrin Alkitab Alkitabiah. Jakarta: Gereja Baptis Independen Alkitabiah GRAPHE, 2001.

Natalia, Desca Lidya, and Hanni Sofia. "Presiden Umumkan Kasus Infeksi Corona Pertama Di Indonesia." Antaranews.Com.

Nugraha, Arie. "Rumah Ibadah Di Bandung Belum Ramah Bagi Disabilitas." Liputan6.Com.

Prabowo, Dani. "Ada Yang Lebih Susah Dari Kita, Yaitu Penyandang Disabilitas." Kompas.Com.

Radissa, Vanaja Syifa, Hery Wibowo, Sahadi Humaedi, and Maulana Irfan. "PEMENUHAN KEBUTUHAN DASAR PENYANDANG DISABILITAS PADA MASA PANDEMI COVID19." Focus : Jurnal Pekerjaan Sosial (2020).

Rifai, Aldi Ahmad, and Sahadi Humaedi. "INKLUSI PENYANDANG DISABILITAS DALAM SITUASI PANDEMI COVID-19 DALAM PERSPEKTIF SUSTAINABLE DEVELOPMENT GOALS (SDGs)." Prosiding Penelitian dan Pengabdian kepada Masyarakat (2020).

Salurante, Tony, Aprianus Moimau, and Filmon Berek. "Tujuan Penciptaan Sebagai Cara Memahami Keberagaman Etika Dalam Kekristenan." Jurnal Teologi Berita Hidup (2021).

Samuel, Kirk. A. Klasifikasi Kebutaan. USA, 1991.

Santoso, Samuel. "Wawancara," 2020.

Simanjuntak, Ferry. Metode Penelitian. Bandung: Sekolah Tinggi Teologi Kharisma, 2016.

Situmorang, Jonar T.H. Bibliologi. Ke 5. Yogyakarta: Penerbit Andi, 2017.

Sugiyono. Metode Penelitian Kuantitatif Kualitatif Dan R\&D. Bandung: Alfabeta, 2011.

Taniharjo, Budisatyo. Integritas Seorang Pemimpin Rohani. Ke 5. Yogyakarta, 2019.

Tim. "Bisa Baca Buku Gratis Dan Alkitab Tulisan Braille, Pasangan Suami Istri Tunanetra Apresiasi Rumah Baca Mutiara Bangsa." Https://Hetanews.Com.

Triyono, Sigit. "Alkitab Dan Disabilitas - Lembaga Alkitab Indonesia." Https://Indonesia.Bible.

Widinarsih, Dini. "Penyandang Disabilitas Di Indonesia: Perkembangan Istilah Dan Definisi." Jurnal Ilmu Kesejahteraan Sosial (2019).

“Arti Kata Tunanetra-Kamus Besar Bahasa Indonesia (KBBI) Online.” KBBI Online, 2021. 